\title{
Evaluating grassland feed resource utilization by extensive livestock farming systems
}

\author{
Leif Jarle Asheim $^{1 *}$ Torbjørn Haukås ${ }^{1}$ Synnøve Rivedal ${ }^{2}$ \\ Odd-Jarle Øvreås ${ }^{2}$
}

\section{Keywords}

Bullock, sheep, pasture feeding, gross margin, farm system, agricultural economics, Norway

Accepted: 21 December 2014; Published: 25 March 2016

\begin{abstract}
Summary
The economy of extensive livestock farming systems in rural areas of Southwestern Norway was investigated by replacing $10 \%$ of intensively-fed bulls with steers and expanding sheep production to reduce pasture encroachment. Meat production was kept stable. The analysis followed an approach with simple budgets and case studies. Low costs of concentrate feed and high meat prices favored intensive beef production, whereas the area and grazing premiums favored extensive steer and sheep systems, utilizing outlying and farmland pastures. Costs of concentrates would decrease by $€ 4.7-4.9$ million and rural employment increase by 139-218 standard man years by the examined change. The risk in farming and community income was political as grazing-based systems were more dependent on governmental subsidies. Future development of livestock farming, governmental subsidies and other measures to enhance grazing were discussed in relation to a few policy scenarios for future meat and feed prices.
\end{abstract}

- How to cite this article: Asheim L.J., Haukås T., Rivedal S., Øvreås O.-J., 2015. Evaluating grassland feed resource utilization by extensive livestock farming systems. Rev. Elev. Med. Vet. Pays Trop., 68 (2-3): 101-105

\section{INTRODUCTION}

Norwegian coastal and fjord agriculture is characterized by small farms scattered along the coastline with arable land in-between heath land, small woodlots, hills and mountains. The climate is mild in the winter, and rainfall is between 2000 and $5000 \mathrm{~mm}$. The landscape is diversified and highly appreciated by visiting tourists as well as by locals. Traditionally, livestock farming has been important in the area and grazing by farm animals has contributed to structuring the vegetation, the biodiversity, and to shaping the

1. Norwegian Institute of Bioeconomy Research, PO Box 115, NO-1431 Ås, Norway.

2. Norwegian Institute of Bioeconomy Research, 6967 Hellevik i Fjaler, Norway.

* Corresponding author

Tel: +47 483522 91; Email: leif-jarle.asheim@nibio.no landscape. The farming systems that utilize grasslands comprise sheep of the Norwegian white or local breeds, dairy cows of the Norwegian red cattle dairy and beef breed, and suckler cow systems of specialized beef breeds. The largest portion of the beef has been and still is produced on dairy farms where surplus calves are reared intensively for slaughtering, but specialized suckler cow systems have increased in later years.

During the last decade the cattle and sheep populations in the counties along the Southwestern coast (excluding Rogaland) declined by 22 and 14\%, respectively (Øvreås, 2012). The open landscapes shaped by centuries of farming are threatened by coniferous plantations and deciduous woods. Their development raises public concern as farming sustains and maintains some of the most species-rich and valuable landscapes in the country. Since postwar, Norway's agriculture has undergone a process of intensification whereby production systems have been depending on purchased energy, fertilizers and feed concentrates which have replaced traditional rural land-use systems. Typically bulls are today reared 
intensively on concentrates and silage and do not use any pasture. Simultaneously, favorable off-farm employment opportunities have facilitated structural changes. However, there are still important structural differences between the smaller coastal farms and the larger inland farms which benefit from more favorable conditions.

An interdisciplinary research project was initiated in 2007 to improve understanding agricultural land-use changes, particularly the roles of socio-economic and biophysical drivers, and examine how extensive grazing for landscape preservation can be promoted. Norwegian farming is conducted within the constraints of the national market and policy-determined premiums. Moreover, import tariffs are applied to keep national prices high for dairy products, meat and concentrates. Special policy measures may be needed to preserve the coastal and fjord landscapes. In the paper we examined the effects of replacing bulls with steers on farm and rural economy, and land use, by increasing the number of steers from 0.5 to $10 \%$ of slaughtered cattle, and expanding sheep farming in the area. The measures would promote grazing and lower the use of concentrates while keeping meat production stable. The objective of the study was to explore the economic conditions in extensive livestock farming in a few scenarios and discuss some possible developments of the industry in the area.

\section{MATERIALS AND METHODS}

The economy of farming systems utilizing pasture in the region was investigated using the farm management approach suggested by Malcolm (2004). Such analysis needs not be complicated, a few disciplines and a few perspectives to explore a few futures would suffice. According to Malcolm, the logic is "what has been and is the situation", "what is likely to be the new situation if I do this or that, or nothing different". He claimed that most good answers can be captured with a few key numbers in a few key budgets. Farm management is about making choices of alternative use of resources to achieve a mix of goals of varying degrees in the face of many unknowns. Whole farm budgeting methods that focus on risky elements as well as case studies can be very useful and enlightening. Pressure on profits from rising real costs and falling real prices forces farmers to change the scale and intensity of their business operations. Farmers need to use the resources they control in a way that is sustainable and to be sustainable they have to be profitable. A challenge facing farmers is to be sufficiently flexible, mentally and financially, to adjust resource management to meet both changed economic circumstances and widely varying climatic conditions (Malcolm, 2004).

Data for budget comparisons were collected from the standard gross margin (GM) calculations for Western Norway (Olsen and Knutsen 2009), NILF (2010) and single-case farm accounts collected for the project. The calculations started with a calf owned or purchased, born in the autumn and weighing 100 kilograms at three months of age. For steers pasture constituted $40-45 \%$ of the net energy intake, half on farmland and half on outlying rangeland, silage $40-45 \%$, and concentrates $10-15 \%$. Bulls, however, would require about $15 \%$ less net energy, no pasture, and about 50\% silage and 50\% concentrates. Although pasture-based meat may be superior, the same price, i.e. $€ 5.25 / \mathrm{kg}$, was applied. Intact males produce a higher yielding carcass with less fat and more edible products, whereas steers may have more desirable meat quality, marbling, tenderness and flavor which may also be favorable to consumers. However, the meat price was slightly higher for bulls. This could be due to the rules of classification used in Norway and the fact that steers only constituted $0.5 \%$ of slaughtered animals and had not been adequately marketed. The price of concentrates was $€ 0.42$ per feeding unit (FEm)
( 1 FEm $\approx 6.8$ megajoules $\approx$ the net energy in 1 kilogram of barley). The variable costs of self-produced silage was $€ 0.20$ and infield pasture $€ 0.10$ per FEm. Outlying pastures were assumed to be free of charge. For steers the cost of castration was added. Castration had to be conducted early and performed by a veterinarian. Moreover, we used data from the records of two to four low-intensity farms in each of seven coastal municipalities, settled in a way similar to that described in the National Farm Account Survey (NILF, 2008).

\section{RESULTS AND DISCUSSION}

Since steers grew more slowly than bulls and were slaughtered at 24 months vs. 15 for bulls (Table I), a changeover from 0.5 to $10 \%$ steers required 12,600 more animals in the area. The steers required an additional 17-18 million FEm of pasture feed, which corresponded to about 3400 ha of farmland and another 37,800 ha of outlying pastures. By utilizing more productive pasture closer to the farm, total area needed was reduced to about 25,000 ha (Asheim and Rivedal, 2011). Beef production decreased by 378 tons because of lower weights, and the use of concentrate feedstuff decreased by 12-13 million FEm.

The variable costs per animal were $€ 287$ higher for bulls, mainly because of the higher cost of concentrates. Annual GM before subsidy payments was highest ( $€ 96 /$ ha) for bulls because they were slaughtered after 12 months. Since steers used pasture areas otherwise left unused, annual GM per hectare of silage area was $€ 75$ for steers, which was $22 \%$ lower than $€ 96 /$ ha for bulls. As steers also obtained more subsidy payments for pasturing as well as for area and cultural landscapes, $€ 933$ vs. $€ 527$ for bulls (Table I), annual GM including subsidies was $€ 240$ /ha for steers compared with $€ 268$ /ha for bulls, i.e. only $10 \%$ lower for steers. Steers needed less supervision when grazing, whereas bulls required daily feeding indoors. Moreover the annual fixed costs would be lower for steers due to ease of handling and slightly simpler buildings with alternative use in the grazing period. Assuming only 50\% higher costs for steers over 24 months of age compared with 15-month-old bulls,

\section{Table I}

Comparing economy of steers and bulls in Southwestern Norway

\begin{tabular}{|c|c|c|c|c|}
\hline & \multicolumn{2}{|c|}{$\begin{array}{c}\text { Bulls } 290 \text { kg, } \\
15 \text { months }\end{array}$} & \multicolumn{2}{|c|}{$\begin{array}{l}\text { Steers } 260 \mathrm{~kg} \text {, } \\
24 \text { months }\end{array}$} \\
\hline & Total & Per year & Total & Per year \\
\hline Gross income $(€)$ & 1,521 & 1,521 & 1,364 & 779 \\
\hline Variable costs $(€)$ & 1,227 & 1,227 & 940 & 537 \\
\hline Gross margin $(€)$ & 295 & 295 & 424 & 242 \\
\hline $\begin{array}{l}\text { Gross margin } \\
\text { [silage area] (€/ha) }\end{array}$ & 96 & 96 & 72 & $41[75]$ \\
\hline $\begin{array}{l}\text { Governmental } \\
\text { support }(€)\end{array}$ & 527 & 527 & 933 & 533 \\
\hline $\begin{array}{l}\text { Gross margin } \\
\text { including support }(€)\end{array}$ & 822 & 822 & 1357 & 775 \\
\hline $\begin{array}{l}\text { GM incl. support } \\
\text { [silage area] (€/ha) }\end{array}$ & 268 & 268 & 229 & 131 [240] \\
\hline Fixed costs $(€)$ & 693 & 693 & 1,048 & 599 \\
\hline Farm profit $(€)$ & 129 & 129 & 309 & 176 \\
\hline
\end{tabular}


the farm profit per year would be better for steers, $€ 176$ vs. $€ 129$ for bulls. However, neither bulls nor steers could sustain high fixed costs, i.e. reasonable investments and use of existing buildings were required to make a profit.

The fencing costs, land degradation caused by trampling in areas with heavy rainfalls or steep slopes, as well as intestinal nematodes had to be paid attention to in steer production; these costs were largely avoided with bulls. The resources of farm pasture, as well as access to outlying pasture and cost of farm buildings were important; however the relationship between the price of pasture and that of concentrates was decisive for the choice. Based on our figures, by increasing the price of concentrates by $€ 0.1$ per FEm, the farm profit for bulls would become negative whereas a similar reduction in the price of concentrates would clearly make bull production more profitable than that of steers. Since bulls and steers eat roughly similar amounts of silage the price of silage was not decisive for the choice. Assuming similar prices for silage and concentrates would make GM before subsidy payments negative for bulls and only slightly positive for steers. Silage in bales could be as expensive as concentrates on an energy basis; however, the silo fixed costs could then be spared.

In a review article Seideman et al. (1982) maintain that the disadvantages of intact bulls compared to steers include undesirable odors, lower quality grade, lower meat tenderness and undesirable meat color. Also heifers produce beef with more favorable technological properties, including more favorable fatty acid composition, and more conjugated linoleic acid than bulls (Weglarz, 2010). Another disadvantage of the intact male is its more aggressive behavior. Castration may be performed to ease handling and improve safety in simpler facilities. In general castration is performed as early as possible out of concern for the animal welfare. However it may be postponed and some farmers reported that castration at less than one year of age may impair their growth (Msanga et al., 2012). Biagini and Lazzaroni (2005) concluded that early and late castrated males showed similar dressing percentages and slaughtering performance for the most important data collected. Bulls were heavier compared to late $(+50 \mathrm{~kg})$ and early castration $(+60 \mathrm{~kg})$, however traditional early castration before puberty seemed better because the operation is easier, and stress and disease are avoided. The animals were given the same indoor feeding of hay and concentrates in the experiment.

Intact males grow more rapidly and utilize feed more efficiently which is important for the economy. Steers may be given hormones to stimulate growth when finishing in feedlots in countries such as the United States or Australia. Such systems have not yet become an issue in Norway as the use of growth hormones is forbidden. The natural conditions with a long indoor feeding period, in which expensive harvested feed has to be used, favor bulls as they grow faster and use less feed for each kilogram of weight gain. In areas where the grazing season is longer, utilization of inexpensive pasture feed may well make steers profitable even though weight gains are lower and it takes longer to reach adequate slaughter weights.

Moreover, when the grazing season is short, systems which have two grazing seasons and slaughtering at the end of the season may be advantaged as indoor feeding is kept at minimum. Also twin calving may keep the number of grazing animals high relative to the ones that have to be fed indoors. This is particularly important in suckler cow systems. According to Morris and Smeaton (2009) twinning can be induced by embryo transfer using either two transferred embryos, or one transferred embryo to supplement the natural one produced by the cow. A second round of inducing twinning in cows which return to estrus after the first round is also possible and researchers are working on a vaccine to produce twinning in cattle. Selection is possible but slow. However, increased calving difficulties, especially in heifers, may be a side effect of increased twinning frequency.

In spite of the short grazing season under Norwegian conditions, grazing as much as possible is preferable and supported by the national government due to concerns for landscape preservation. However, the area and cultural landscape premium was $40 \%$ lower for permanent farm pasture than for other farmland. Raising them to the same level would increase GM to $€ 250$ per hectare of silage area for steers which is only 7\% lower than GM for bulls. Targeted regional subsidy payment for pasture clearance might also be increased to control pasture encroachment. A calculation assuming $€ 0.3$ lower meat prices showed a decrease in annual profit to $€ 38$ for bulls and to $€ 130$ for steers. Norwegian beef farmers are at risk of lower tariffs and meat prices following more international competition from a new agreement of the World Trade Organization (WTO) or other organizations. Calculation with a $€ 0.3$ per kilogram increase in the meat price revealed that farm profit was rather similar for bulls $(€ 220)$ and steers $(€ 222.5)$. As a risk, increased international prices for beef following higher meat consumption for example in China and India would favor bulls because of the shorter feeding time. However, the road is long before Norwegian beef becomes competitive. In a longer perspective higher beef prices can also be accompanied by higher prices for concentrates.

Data from eight low-intensity coastal sheep farms and 15 medium-intensity regional farms in the region (Table II) were used to

\section{Table II}

Average account results of low-intensity coastal sheep farms in Southwestern Norway compared with sheep farms in the region (2007-2009)

\begin{tabular}{|c|c|c|}
\hline Type of farms (num.) & Coastal (8) & Regional (15) \\
\hline Farm area [hired] (ha) & $18[6.8]$ & $16[6.4)$ \\
\hline $\begin{array}{l}\text { Yields of roughage } \\
\text { and pastures (Fem*/ha) }\end{array}$ & 1,593 & 2,231 \\
\hline $\begin{array}{l}\text { Num. of breeding sheep } \\
\text { [lambs/sheep] }\end{array}$ & $66[1.17]$ & $102[1.30]$ \\
\hline $\begin{array}{l}\text { Meat production } \\
\text { (kg/breeding sheep) }\end{array}$ & 20 & 25 \\
\hline $\begin{array}{l}\text { Purchased fertilizers } \\
\text { [herbicides] (€/ha) }\end{array}$ & $82.6[0.2]$ & $120.7[2.7]$ \\
\hline $\begin{array}{l}\text { Concentrate feed } \\
\text { ( } € / \text { breeding sheep) }\end{array}$ & 36 & 33 \\
\hline Total labor input [family] (h) & 1,402 [1274] & $1,731[1366]$ \\
\hline Livestock products $(€)$ & 7,336 & 14,583 \\
\hline Agricultural subsidy payments $(€)$ & ह) 16,343 & 25,948 \\
\hline $\begin{array}{l}\text { Area and cultural } \\
\text { landscape subsidy }(€)\end{array}$ & 5,673 & 7,051 \\
\hline Animals and relief workers $(€)$ & 7,511 & 11,799 \\
\hline Other subsidies (€) & 3,158 & 7,098 \\
\hline Other farming income $(€)$ & 1,756 & 3,789 \\
\hline Fixed and variable costs $(€)$ & 20,792 & 32,558 \\
\hline Net farm income $(€)[€ / h]$ & $4,643[3.6]$ & $11,762[8.6]$ \\
\hline
\end{tabular}

$* \mathrm{FEm}=$ feeding unit $(1 \mathrm{FEm} \approx 6.8$ megajoules $\approx$ the net energy in $1 \mathrm{~kg}$ barley $)$ 
calculate replacing lost beef with mutton and lamb meat. The farm area of both systems was rather similar, around 17 hectares and used for roughage and pasture. Both farm groups hired between 6 and 7 hectares of farmland. The sheep used outlying pastures like the steers. The yields were $29 \%$ lower, the costs of fertilizers and liming of the soils were $32 \%$ lower, and the low-intensity coastal farms hardly ever used herbicides. None of the coastal farms were organic but clearly the low-intensity farming systems resembled organic systems.

In comparison to the regional farms, on the coastal farms the number of sheep was 35\% lower, they were of a smaller coarse-fiber breed, and the number of lambs per breeding sheep was lower (1.17 vs. 1.30), resulting in lower meat production per breeding sheep. The lambing percentage has gradually increased in Norwegian sheep farming; however, there is space for improvement on both the coastal and regional sheep farms. This would increase in particular feed uptake from pasture.

The income from livestock product sales of the low-intensity coastal farms was nearly half that of the regional farms (Table II) in spite of a similar meat price $(€ 3.7 / \mathrm{kg}$ ). Lower rates of subsidy for permanent pasture negatively affected subsidy payments to the coastal farms with much permanent pasture farmland. The price of wool was also lower, $€ 3.2 / \mathrm{kg}$ on the coastal farms vs. $€ 3.9 /$ $\mathrm{kg}$ on the regional farms. The difference in subsidies for animals and relief work, and price subsidy payments largely reflected differences in flock sizes and productivity. Both the variable and the fixed costs were lower on a per sheep basis in the coastal farm group, but this did not compensate for the lower productivity, wool prices and subsidy payments. The coastal sheep farmers also had lower incomes from other farm and off-farm businesses and wages.

The sheep farmers purchased 4.2 and 3.1 FEm of concentrates per kilogram of meat, respectively, more than that assumed for steers (1.2) but less than that for bulls (4.6). The overall costs of concentrates following the transition to $10 \%$ steers would be lowered by $€ 5.4$ million. However, replacing the lost 378 tons of beef with mutton and lamb meat would require an additional $€ 0.5-0.7$ million for concentrates for sheep. Expanding mutton and lamb meat production would require production on an additional 286 low-intensity coastal farms or 148 medium-intensity regional farms. Rural employment would increase by 218 and 139 standard man years $(1845 \mathrm{~h})$, respectively, for the two farming alternatives.

There are resources available for increased grazing in the southwestern region of Norway that may be utilized by steers or sheep. The calculations showed a slight increase in farm profit for steers in relation to bulls, however the margins were small. Neither bulls nor steers sustained high costs. Particularly the cost of farm buildings and fences had to be kept at a reasonable level. A scenario with considerably higher international prices for concentrates, because for example of an increased demand, might trigger a transition to steers. The availability of infield and outlying pasture resources on the farm may be decisive for the transition. The pastures must be suited for steers and risks of land degradation from rain or steep slopes, as well as health problems related to nematodes should not be overlooked in this wet climate region. A limited increase in the number of steers might be advantageous for the landscape but one should probably not aim for a huge increase. Feed constraints and availability of cheap concentrates favor bulls whereas ample local pasture resources and a long grazing season favor steers. Slaughtering at the end of the grazing season and increasing twin births are possible ways for Norwegian beef production to increase the use of pasture in cattle meat production.
Steers will also be favored by low meat prices following lower tariffs under, in particular, new international agreements. However, this may depend on Norwegian agricultural policies and whether governmental payments for area and cultural landscape, and for outlying or infield grazing can be kept as green subsidy. Green subsidy can be kept without any restraints but to qualify it must not, or to a very limited extent, impact international trade. Steers are favored if grazing and landscape subsidy payments can be kept as green subsidy. Policy subsidy measures are restricted by international trade concerns and national concern for food prices. Should encroachment in the region be controlled, the special subsidy for outlying grazing could be raised. Similar rates of landscape subsidy scheme for farmland pasture and leys could also be introduced. The rates are currently about $40 \%$ lower for pasture land, whereas from a landscape perspective, permanent pasture particularly with grazing animals might be as valuable as leys for silage. Changing the special subsidy for farmland pasturing does not necessarily affect encroachment. Bulls are favored in a scenario with high meat prices because of the shorter time to make them ready, but bulls also depend on low concentrate prices. In a scenario with both high meat and feed prices steers would probably do better and that would also be the case if the market sustained additional payment for pasture-based beef. That may depend upon consumers' preferences.

\section{- CONCLUSION}

The increased use of local resources following a limited 10\% transition from bulls to steers on dairy farms would improve self-sufficiency by reducing the use of purchased concentrates by about $€ 5.4$ million. However, if the lost meat was replaced by mutton and lamb meat the net reduction would be between $€ 4.7$ and $€ 4.9$ million. Efforts to lower the use of concentrates for sheep should be given priority if concentrate prices increase. By expanding sheep farming to this extent rural employment in the region would also increase in both sheep farming alternatives. In spite of lower costs of fertilizers and herbicides and lower fixed costs, expanding low-intensity coastal sheep farming would give considerably poorer economic result than medium-intensity regional farms. The result is due to lower subsidy payments, lower productivity as well as lower product prices on the coastal farms. Because of the short grazing season, improved lambing percentage on farms in the region might be a way to enhance the use of pastures by sheep.

\section{REFERENCES}

Asheim L.J., Rivedal S., 2011. Ekstensiv kjøtproduksjon for å redusere attgroing. (Extensive meat production for encroachment control) (Herd No 2) [in Norwegian]. Buskap (2): 52-53

Biagini D., Lazzaroni C., 2005. Effects of castration age on slaughtering performance of Pimontese male cattle. Ital. J. Anim. Sci. (Suppl. 2), 4: 254-256

Malcolm L.R., 2004. Farm management analysis: a core discipline, simple sums, sophisticated thinking. Aust. Farm Bus. Farming Sys. Manage. J., 1: 45-56

Morris S.T., Smeaton D.C., 2009. Profitable farming of beef cows. Massey University, Institute of Veterinary, Animal and Biomedical Sciences, Palmerston North, NZ, 137 p.

Msanga Y.N., Mwakilembe P.L., Sendalo D., 2012. The indigenous cattle of the Southern Highlands of Tanzania: distinct phenotypic features, performance and uses. Livest. Res. Rural Dev., 24, 110 
NILF, 2008. Account results in agriculture and forestry, 2007. NILF, Storgata, Oslo

NILF, 2010. Handbok for driftsplanlegging (Handbook of farm planning) [in Norwegian]. NILF, Storgata, Oslo

Olsen A., Knutsen H., 2009. Dekningsbidragskalkylar Hordaland, Sogn og Fjordane, Møre og Romsdal 2009/2010. (Calculations of gross margins for Hordaland, Sogn og Fjordane, Møre og Romsdal 2009/2010) [in Norwegian]. NILF, Storgata, Oslo. (NILFmemorandum No 10)
Øvreås O.-J., 2012. Endringar i jordbruksareal og dyretal på Sør- og Vestlandet 1989-2011. (Changes in agricultural area and animals in Southwestern Norway 1989-2011) [in Norwegian]. Bioforsk Rapport, 7 (17): 1-29

Seideman S.C., Cross H.C., Oltjen R.R., Schanbacher B.D., 1982. Utilization of the intact male for red meat production: A review. J. Anim. Sci., 55: 826-840

Weglarz A., 2010. Quality of beef from semi-intensively fattened heifers and bulls. Anim. Sci. Pap. Rep., 28 (3): 207-218

\section{Resumen}

Asheim L.J., Haukås T., Rivedal S., Øvreås O.-J. Evaluación de la utilización de recursos de alimentación de pastizales por los sistemas de cultivo extensivo de ganado

Se investigó la economía de los sistemas de ganadería extensiva en zonas rurales en Noruega del suroeste, reemplazando $10 \%$ de los toros alimentados intensivamente con novillos y expandiendo la producción ovina para reducir el hacinamiento de los pastoril. La producción de carne se mantuvo estable. El análisis siguió un enfoque con presupuestos simples y estudios de casos. Bajos costos de alimento concentrado y altos precios de la carne favorecieron la producción intensiva de res, mientras que primas al pastoreo y por zona favorecieron los sistemas extensivos de ovinos y de novillos, utilizando pastizales en fincas y terrenos circundantes. Los costos de los concentrados disminuirían de 4,7-4,9 millones euros y el empleo rural aumentaría de 139-218 años hombre estándar con el cambio estudiado. El riesgo para la ganadería y el ingreso comunal fue político, ya que los sistemas basados en pastoreo fueron más dependientes de subsidios gubernamentales. El futuro desarrollo de la producción ganadera, subsidios del gobierno y otras medidas para impulsar el pastoreo fueron discutidos en relación con algunos escenarios reguladores de los futuros precios de la carne y los alimentos.

Palabras clave: buey, ovino, alimentación en pastoreo, margen bruto, sistema de explotación, economía agrícola, Noruega
Mots-clés : bœuf, ovin, alimentation au pâturage, marge brute, système d'exploitation agricole, économie agricole, Norvège 
